\title{
The Painful Analgesia of Cotard's Syndrome
}

\author{
Yorgos Dimitriadis*
}

CRPMS, EA 3522 UFR “Psychoanalytic Studies”, Paris-Diderot University, 8 rue Albert Einstein, 75013 Paris

\begin{abstract}
In the present paper, we look into what is painful psychical analgesia in relation to what $19^{\text {th }}$ century clinicians have named "moral pain" in melancholia, and more particularly in the delusion of negation described by the French psychiatrist Jules Cotard in 1880, a form of delusion that can be seen mostly in cases of chronic anxious melancholia. This condition is characterized by a painful absence of emotions, which occurs when the subject, in the Lacanian sense of the word, ceases to be touched by the signifiers, and consequently ceases to exist as a subject. Hence, these patients often declare themselves to be already dead or incapable of dying. The psychoanalytical approach to this delusion allows an understanding of the "lack of lack" concept, as these patients, having lost the lack, affirm that their body's orifices are clogged, that they have lost their mental vision, that they miss various visceral organs etc. The completeness of their body - the absence of orifices - can sometimes attain universal dimensions and these patients can thus identify themselves to the universe, which contains everything. The delusion of negation teaches us something important concerning the essence of desire, in relation to what has been named by Lacan area-between-two-deaths. This Lacanian concept refers essentially to the tragic hero, but also, more generally, to the lonely condition where anyone's desire should be able to exist beyond any narcissistic commitment, which means beyond the pleasure principle as well.
\end{abstract}

Keywords: Analgesia, Cotard, Czermak, delusion, Lacan, melancholia, moral, negation, pain, painful, psychoanalysis.

\section{THE PAINFUL PSYCHICAL ANALGESIA OF MEL- ANCHOLIC PATIENTS}

According to Georges Lanteri-Laura [1], the term moral pain (douleur morale) was probably first used by J. Guislain [2] (1797-1860) in Belgium, in 1833: "In the first place, mental disease is a condition of discontent, anxiety, suffering: there is pain, but it is a moral pain, intellectual or cerebral, depending on how we choose to conceive it. To say that a mental disease is a disorder of judgment and logic would be incorrect: it would mean considering the symptom as the primary phenomenon", (p.1). J.Guislain named "phrenalgia" this primary phenomenon of every mental disease. In the middle of the $19^{\text {th }}$ century, the German W. Griesinger [3] (1817-1868) adopted that conception in relation to moral pain (Schmertz), that it precedes any possible evolution of the mental disease and transforms inner experiences and the understanding of the world. Moreover, it is a condition that alienates the subject from its own self. The French J. Séglas (1856-1939), around the end of the $19^{\text {th }}$ century, restricted the use of the term moral pain to the sole melancholia, in which, according to him, there is a paradoxical experience that connects two seemingly contradictory dimensions: that of moral pain and that of insensitivity. Concerning moral pain, J. Séglas [4] states: "When it manifests itself, it tends to fill the whole of the conscience, which, as we say, does not contain more but the word pain (Schuele). In the same way that an intense physical pain which impinges upon one of our senses is followed by insensitivity, moral pain will cause to

*Address correspondence to this author at the CRPMS, EA 3522 UFR "psychoanalytic studies", Paris-Diderot university, 8 rue Albert Einstein, 75013 Paris; Tel: 0033611690528; Fax: 0033611690528 ;

E-mail: dimitriadisyorgos@gmail.com the melancholic either a state of insensitivity or one of psychical lower sensitivity”, (p.290). In Germany, during the same period, Emil Kraepelin [5] (1856-1926), while introducing his own term of manic-depressive psychosis in psychiatry, noted that the depressed is in a condition where he is unable to be emotionally moved, in a state of depersonalization to such a point that even his own body feels estranged: "In addition to the feeling of sorrow, there is an inhibition of the emotional movements which would be the opposite of the maniac's intense emotionalism. It is this particular reduction in the ability to be moved, this loss of intimate interest in events that happen around us, which is principally experienced as painful...,one realizes that the patients are extremely insensitive to bad news. It is usually only during the convalescence that normal pain resumes...In several cases, the patients describe their inner life as a state, which we call depersonalization. The impressions they receive from the outer world acquire an estranged character, as if they were coming from some far away country, and do not generate ideations within their conscience. They get the impression that their own body does not belong to them, that their facial attributes have been totally transformed and that their voice has acquired a metallic tone", (p.57-58). In this paper, I will look into the most extreme form of this painful psychical analgesia that occurs in a clinical condition, which may develop mainly in chronic forms of melancholia, and which was first described by the French psychiatrist Jules Cotard under the term "delusion of negation". Following the description of the syndrome and of the hypotheses proposed by Cotard and the clinicians of his time on its etiology, I will proceed to some hypotheses of my own based on the works of some psychiatrists and psychoanalysts, more specifically on those of Marcel Czermak regarding the psychoanalytical significance of 
the delusion of negation. In the same time, I will be addressing the issue of painful psychical analgesia in melancholia from the, so-called, "lack of lack" point of view.

\section{HISTORY AND DESCRIPTION OF THE DELUSION OF NEGATION}

Contemporary psychiatry has practically ceased to deal with the detailed analysis of delusions, which are mostly considered as the manifestation of a deficient brain and of no particular interest as to their specific content. Things were slightly different during the end of the nineteenth century. The alienists, the doctors who were dealing with mental affections in French speaking countries, were conscious of the fact that they possessed but a few therapeutic means. Their patients were usually inmates of specialized institutions on the outskirts of cities, created upon the standards of the two pioneers of psychiatry in France Pinel's and Esquirol's views on mental healthcare. Jules Cotard was also such a pioneer who worked in Vanves, a suburb of Paris. During his short life, having died in 1889 at the age of 49 , he wrote five articles concerning a rare type of delusion which can be encountered mostly in chronic forms of anxious melancholia and which will be the subject of this paper. The first of those articles was published in 1880 under the title "A hypochondriac delusion in a type of severe anxious melancholia" [6]. In his second paper on the subject, published in 1882, he changed the delusion's name into "delusion of negation" [7]. $\mathrm{He}$ chose this name because the patients in question, for the most part middle-aged women, in addition to presenting the usual symptoms of anxious melancholia, such as terrible remorse and fear of impending punishment, thoughts of unworthiness and disaster, great anxiety and psychomotor excitement, presented some other manifestations as well. The said manifestations were ideas of damnation and possession from some foreign power (usually that power being the devil), suicidal tendencies, self-mutilation and more specifically hypochondriac ideas of nonexistence and destruction of several body organs and body orifices, or even thoughts of destruction of the soul and of God. Thoughts of the destruction of body organs were often going hand in hand with those of the body's complete destruction and of death. Strangely though, while the patients affirmed that they were already dead, they also often believed that they were unable to die and that they were doomed to live eternally. Later on during the disease's evolution, to the thoughts of immortality, i.e. of exaggeration concerning the time they were going to live, thoughts of exaggeration concerning their own size. They believed that their size had grown remarkably and that some of their limbs, or even their whole body, had grown to such an extent as to become of cosmic proportions, thus occupying the whole universe.

That used to be and still is the basic clinical outline of the delusion of negation, even if there can be a few variations from patient to patient. For example, when talking about the first paper's patient, Cotard [6] says "Miss X...assures us that she does not have any brain, nor nerves, breasts, stomach or intestines; she is left but with the bones of her disorganized body (these are her own expressions). This delusion of negation branches out to the metaphysical ideas that were once for her the object of the most unwavering faith; she does not have a soul, God doesn't exist, and nor does the devil. Miss $\mathrm{X} . .$. , being a disorganized body, does not need to eat in order to stay alive, will not die from natural causes, will live eternally except if put to the fire - fire being the only possible end for her", (p.168). One of Monique Grignard's [8] patients, an elderly woman of 77 years old who developed the syndrome in 1980 following a surgical operation for visceral prolapse, affirms that her rectum is clogged, that she is unable to urinate, that nothing can go through anymore and she tries to unblock her orifices herself by introducing various objects in them. Her heart is not beating anymore. She is not breathing, she has no lungs. She refuses to be fed since nothing can pass through after the surgery. Her intestines have become narrower, have risen, have rotted and are completely clogged. She complains that she never sleeps. All of her orifices are clogged: her vagina, her nose, even her ears, which is why she is unable to hear. At this point, I should mention that the idea of clogged innards is often encountered in elderly people suffering from depression. Other patients suffering from delusion of negation affirm that they are no longer able to represent anything in their imagination. The famous Charcot, who had been Cotard's teacher, had mentioned before him some cases where the patients were saying to have lost their mental vision. The third of Cotard's [9] papers on the syndrome, published in 1884, was given the title: "The loss of mental vision". In it he mentions that some of the patients "were unable to bring back to memory some familiar monuments, landscapes or objects". One of Marcel Czermak's [10] patients suffering from the syndrome affirmed that he was not feeling anything by looking at objects. This has to do with the analgesia which was considered by Cotard as the main characteristic of that particular condition. The patients may not feel pain because they are unable to feel anything, but they suffer precisely from this inability to feel even pain, from the fact that nothing can affect them. In1983, one of Jean Paul Baumont's [11] patients declared: "My brain does not register anymore, I have a void, a black hole inside my head, I feel empty. I do not have feelings...I do not have a personality, I do not have anything that could enable me to think and to talk, I do not have thought in order to understand what the others say, I can't speak, I don't know how to speak", (pp.33-34).

The persons suffering from Cotard's syndrome, as the delusion of negation has been named, state that they are dead, but, as has been mentioned before, paradoxically declare at the same time that they are doomed to live on eternally in that situation. This situation points to the religious myths concerning life after death, and more particularly the one about the Wandering Jew cited by Cotard himself. However, it also points to the Catholics' purgatory, the Koran's 'A'rāf or even to Hecate's abyss where, according to Plutarch, the soul loses its thymia. Another of Jean Paul Baumont's [11] patients, who developed the syndrome following surgery and chemotherapy for skin melanoma, described his condition as hovering between life and death. He was describing himself as walking next to life, next to a life that isn't life, as not being in the same life as other people. He was saying that time doesn't exist, that it is an infinite time that will never end. That there is no divide between past and future and that he is stuck in an indefinite present where all differences have vanished. That each day is the same as the other, a universal day that represents millions of years, that day and night have become one, that time cannot be measured and that the same moment is eternally repeating itself. There are no cycles, no 
calendar, no Monday, Tuesday, Wednesday or Friday, no dates, and no alternation between day and night. In the same way, distance too did not exist for that patient. He declared being "always in the same place. Everything is like being in front of the same faces that never move. I am in hell. Cotard's syndrome had almost been forgotten as it had become very rare after the discovery of effective therapies against melancholic state. As Cotard stated, the syndrome developed mainly in chronic anxious melancholia cases, but with the various therapies, antidepressants, neuroleptics and electroconvulsive therapies, the affection does not become chronic enough to evolve into Cotard's syndrome. Authors have mentioned that the syndrome can also develop, with some differences in its clinical outline, in cases of paranoia and advancing general paralysis. Nowadays, the syndrome appears mainly under the aspect of hypochondriac ideas of denial.

\section{ETIOLOGY OF THE DELUSION ACCORDING TO THE CLINICIANS OF THE TIME}

In 1884, Cotard [9] sought to explain the etiology of the delusion of negation by the loss of mental vision previously mentioned. The delusion's etiology, according to that thesis, was the following: the moral pain, which according to Griesinger's teachings was at the center of the issue of melancholia, is manifested through mood disorder, displeasure, indifference, disgust and sensation disorder, the patient thus perceiving with confusion the objects of the external world towards which he feels estranged. It makes no difference whether the denial concerns his sentimental and mental abilities or his body's organs. We talk about moral hypochondria (hypocondrie morale) in the first situation and about somatic hypochondria in the second. In both situations, the problem resides (according to the theory, popular at the time, of the localization of functions in various areas of the brain) in the cerebral cortex where sensory images of the organs are registered. Therefore, the denial of the body organs and personality is related to the absence of subjective representations (i.e. the loss of mental vision) that normally allow the sense of existence as a whole and of each organ separately. This first explanation is in agreement with the mechanistic and psychaesthetic tradition widespread at the time. The theory states that the disorder of various brain areas causes various sensation disorders, which in turn will cause mental disorders.

In 1887, Cotard [12], influenced by the philosophical theory of aesthetics (fashionable at the time) and by Charcot's model on aphasia, revised his theory in his fourth paper on the delusion of negation entitled "On psychaesthetics or the psychomotor origin of the delusion". Nevertheless, in the case of Cotard's syndrome, the damage resides in object's representations and not in the center of verbal representations as stated by Charcot in the case of aphasia. According to Griesinger, in the case of mania, then considered to be the opposite of melancholia, the pathological excitement concerns the corporal movements, as well as speech and the internal movement of thinking. That inner hypersensitivity is transferred to the ego and leads to the idea of the self rising to a level equal to that of the kinetic activity. As a result, thought undergoes a certain automatism, a well-known term to the clinicians of the time from the studies of Baillarger in the middle of the $19^{\text {th }}$ century. The maniac doesn't believe anymore who says that he is controlling his thoughts, thus allowing ideas of divine origin and other similar ones to oc- cur. On the contrary, it is the loss of motion energy which explains the painful moral predisposition, the loss of mood, the sadness and the despair that characterize depressions of the melancholic type. In melancholia, thoughts of possession by a foreign power, usually Satan, appear just as thoughts of divine inspiration appear in mania.

However, as noticed by Jorge Cacho [13], whereas Cotard, in his first psychaesthetic pathogenic theory, considers ideation disorders as secondary to the emotional disorder, in the second - the psychokinetic one -, he tends to consider the opposite, that is to say that it is rather ideation and will which cause sentimental disorders (and the hallucinations). From a contemporary point of view, we may agree with J. Cacho that the difference between the two theories is tenuous at most. Lastly, Jules Séglas [14], probably the most important clinician of the time, follower of Cotard's work and author of a study on the syndrome, will suggest in 1897 a somewhat different pathogenic view regarding the syndrome: the reduced capability of the patients to dispose of the word images - according to Cotard, due to the psychomotor damage -, as well as the related reduction of their capacity in mental integration, cause them subsequently an inability to control the words' images. Hence, the patients find themselves unable to summon or to move and transform these images. On one hand, this generates obsessive ideas and on the other, the continuous automatic repetition of the same series of thoughts and images (mentisme). Thus, the patient feels the cleavage of his personality, which provokes the moral pain. Hence, Jules Séglas believes that moral pain comes from the patient's difficulty for mental synthesis. This conception was inspired by the theory of Cabanis regarding cenesthesia who considered conscience as related to the awareness of organ functioning. As to the thoughts of immortality, J. Regis [15], at the congress on the subject of the delusion of negation that took place in the French city of Blois in 1892, argued that they are a result of logic. Since the patient's body is not normally organized, he infers that he is unable to die and that he is doomed to live on in eternal anguish. I will mention here that it is Regis who, during that same congress, suggested naming the delusion of negation "Cotard's syndrome" and history retained that suggestion. Concerning the ideas of size increase, while they constituted the topic of Cotard's [16] last paper on the subject "The delusion of enormity (énormité)" published in 1888, there were no hypotheses on their etiology, although they were related to the evolution of the immortality ideas. Nevertheless, the paper raised the question of a differential diagnosis from megalomaniac ideas within the persecution delusion and from the mixed mental affections described mainly by Séglas [17].

\section{PSYCHOANALYTICAL SIGNIFICANCE OF CO- TARD'S SYNDROME PAINFUL ANALGESIA}

After Cotard, and a short time afterwards, the works of Séglas [18] and other psychiatrists of the time, the delusion of negation remained practically in oblivion for almost a century. As far as I know, apart from Salomon Resnik's [19] article titled "Cotard's syndrome and depersonalization" (1954) and a reference by Jacques Lacan [20] in 1955, the subject has not been addressed in psychoanalytical texts until 1983. The subject was addressed that year once again by the psychoanalytic school Association Freudienne and more specifically by Marcel Czernak [21] in his speech "The 
psychoanalytical significance of Cotard's syndrome", at the congress "Psychoses" organized by this psychoanalytical school. In 1992, a congress [22] on the subject was organized by the Association Freudienne and in 1993, Jorge Cacho [13], member of that same school, published his thesis on the dilution of negation, focusing mainly on the history of the syndrome. As I mentioned before, in 1955, Lacan [20] referred to the syndrome during his seminar. He said the following things: "Elderly women suffering from the syndrome, who declare that they do not have mouth and stomach, and that they will never die, have a close relationship with the realm of moons. They have identified themselves with an image from which any opening, any expectation, any void of the desire is missing; i.e. what properly constitutes the attribute of the oral orifice is missing", (p.278). Here, I would like to mention that the French word "béance", which means "opening", meant "desire" in the $12^{\text {th }}$ century. Lacan [20] continues: "To the extent that the "being's' identification to its pure and simple image is attempted, there is no place left for change, i.e. for death. In their case, the fact that they are dead and that they cannot die corresponds to the fact that they are immortal just like the desire. To the extent that the subject symbolically identifies itself to the imaginary, it realizes, in a way, the desire", (p.278).

I will attempt to comment on Lacan's dense words, which stir the subject of the mirror stage and its importance in psychosis. According to Lacan, the psychotic attempts to identify his "being" with his image. I will not dwell upon that particular subject. As far as the issue of desire is concerned, I will leave it aside in order to focus on the issue of lack. This lack of opening, or "lack of lack", in Cotard's syndrome patients somehow creates an unconscious image of the body as a compact orb which is filled with everything, or at least with what may be missing from the subjects in order for them to desire, i.e. with what constitutes their psychical reality. Consequently, these patients are not absent from the imaginary world, but from the symbolic world, the world that constitutes them as specific subjects. They disconnect from the chain of their signifiers and that is why the world ceases to mean anything to them. They are dead to the chain of their signifiers (as the chain's subjects) while their world remains a kind of pure imaginary, exempt of any symbolic grip that would allow them to think and change something. Here, I refer not so much to conscious thought, even though it suffers as well, but rather to the metaphorical and metonymical processes, that take place in the unconscious and of which we have a more direct view through dreams. This explains the fact that they believe their world to remain forever unchanged. Besides, as I stated before, the patients withhold their body's objects - urine and feces -, do not feed, cannot remember images and when looking at objects, do not feel or think of anything. When they listen to other people, they are unable to grasp the content of what is being said. According to Lacan, the petit $\alpha$ objects, the feces, the breast, the gaze and the voice are reintegrated into the now compact body instead of being separated from it from the cut that the signifiers cause to the body. According to Czernak [21], analgesia, the loss of sensation of pain, corresponds to the "lack of lack". The insomnia the patients complain about is not an objective insomnia. One of Czernak's patients [21] was saying that "when well, he could feel sleep approach- ing: the heavy eyelids, the need to close his eyes. When sick, he was falling asleep immediately and waking up without feeling that he was waking up", (pp.214-215). Czernak [21] affirms that "these patients who live in that world from which nothing is missing identify themselves to the object that could be lacking', (p.223) (the petit $\alpha$ object, cause of the desire according to Lacan) and can sometimes commit suicide or ask someone to kill them so as the object - that they have become themselves - can finally become absent from the world.

Given the relationship they have in regards to the lack and to death, these patients remind us of another type of patients. First of all, the "death of the subject" reminds us of what is experienced by psychotic patients. Nevertheless, psychotics usually express the death of the subject as an end-of-theworld experience, and not as a personal death like Cotard's syndrome patients. This particular point of the subject's death experience, for instance in paranoid schizophrenia or in paranoia, precedes the attempt to form a new relationship with the world through the delusion. The paranoid German judge Schreber (in Freud's [23] famous analysis of his delusional biography) experienced the moment of the subject's death when, reading the newspaper, he moved on to another newspaper column, more precisely the obituary one. Finally, after various psychotic disorders, as for example his catatonic crises, he stabilizes years later through the delusional metaphor of his identification to "God's wife". In a sense that this identification locates the "real", it frames it. That way, he avoids the effects of the real's fluctuations whose transformations he would otherwise be bound to suffer constantly. By transforming himself into a woman, he ceases to resist to the persecution he suffered from the enjoyment (jouissance) of the other. He accepts this enjoyment through his megalomaniac identification to God's wife whom he represents by dressing up into a woman in front of his room's mirror.

I previously mentioned the elderly suffering from depression and their hypochondriac ideas concerning their digestive and urinary systems, as well as their hypochondriac insomnia. G. Ferrey [24], a French psychiatrist for the eldelrly, notes that denial, in the case of elderly patients suffering from depression or from Cotard's syndrome, concerns not so much the organs themselves, but rather their function. These patients do not suffer from nosophobia but complain that their food and their bodily discharges cannot pass through. The alcohologist Jean-Paul Descombey [25] emphasises how important it is for alcoholics to be able to ignore death, to be thanato-agnosic, to be able to believe that death can reach them only by accident. Also, that if they contract the syndrome of Korsakoff (anterograde amnesia) after years of alcohol consumption, they are now living a timeless existence. Of course, drug addiction is not very dissimilar in regards to thanato-agnosia, that is to say the tendency of drug addicts to continuously provoke death, but also the tendency to create new needs for themselves, which could be something not unlike artificial body orifices. When they pierce themselves, they create not only metaphorical orifices on their body, but very real ones. I would also like to mention the trend of piercing, the tendency of some people to make holes on their body, or the even more striking tendency of some people to self-mutilate by way of surgical operations or by themselves. I would like also to mention briefly the "phallus hypochondria" (p.39), which is how Marcel Czer- 
mak [26] names the request for sex change in the case of transsexuals. All of these situations are probably attempts to create a lack into the real of the body, where the symbolic function is unable to create a cut, i.e. a hole on the body. These are very different situations from the obsessive's condition who lives in a constant postponement in regards to his desire, i.e. who poses as dead in regards to his desire.

Finally, concerning Cotard's syndrome patients' life between two deaths, I would like to mention the area "between-two-deaths", (pp.415-421), described by Lacan [27] as the area of desire, (Fabienne Hulak [28] and Rémi Tevissen [29] also remind that issue more recently) when one finds himself to be like some tragic hero, like Sophocles' Antigone for example, who is bound to realize that which constitutes the desire, to honor her dead brother Polyneices even if this means her own death. Like Sophocles' Electra who affirms being dead in life. Like Oedipus to whom the chorus cries

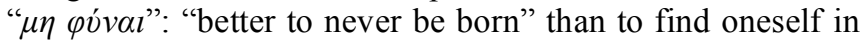
Oedipus' terrible position. Like Hamlet, who needs to face Ophelia's death and be mortally wounded in order to finally support the act that he was repeatedly putting off, i.e. the revenge of his father's death by killing his uncle Claudius. The tragic hero is situated in that area where, even if condemned in regards to his narcissistic love, or even if doomed to die - i.e. beyond the principle of pleasure -, he still remains beholden to desire. Furthermore, from this position only may he be able to uphold his desire. This is someway probably the common fate: to be able to desire only as mortal men. That is demonstrated by the tragic hero from a point of view that more often than not leads quickly to his death, as in the example of Antigone. Whereas to accept one's desire, often after having experienced it at the level of solitude, as a desire that concerns one alone, can on the contrary impel one towards life.

\section{CONFLICT OF INTEREST}

The author confirms that this article content has no conflict of interest.

\section{ACKNOWLEDGEMENTS}

Declared none.

\section{PATIENT'S CONSENT}

Declared none.

\section{REFERENCES}

[1] Lanteri-Laura G. Introduction historique et critique à la notion de la douleur morale en psychiatrie. In: Tevissen R, Ed. La douleur morale, Paris, Editions du temps. 1996; pp. 9-28.

[2] Guislain J. Leçons orales sur les phrénopathies. Paris-Bonn: L. Hebbelynck éditeur; 1852 .

[3] Griesinger W. Traité des maladies mentales: pathologie et thérapeutique. tr. Jules Baillarger. Paris: Delahaye; 1965.

[4] Séglas J. Dixième leçon, De la mélancolie sans délire. In: Leçons cliniques sur les maladies mentales et nerveuses, Salpêtrière 18871894. Paris, Asselin et Houzeau 1895; 282-96.
[5] Kraeplin E. La folie maniaque-dépressive. trad. Fr. by G. Poyer. Ed J. Millon, Coll. Mémoires du corps; 2013.

[6] Cotard J. Du délire hypocondriaque dans une forme grave de la mélancolie anxieuse. Annales médico-psychologiques. 1880; 4: 168-174.

[7] Cotard J. Du délire de négation. Archives de Neurologie 1882; 11: $152-70$ \& 12: 282-96.

[8] Grignard M, Mme F. un Cotard méconnu. In: Baumstimler Y, Cacho J, Czermak M, Dir. Délire des Négations, Actes du Colloque des 12 et 13 décembre 1992, Paris: Le discours psychanalytique Éditions de l'Association Freudienne Internationale 2001; pp. 5765 .

[9] Cotard J. Perte de la vision mentale dans la mélancolie anxieuse, Archives de neurologie 1884; 21: 56-68.

[10] Czermak M. Signification psychanalytique du syndrome de Cotard. In: Baumstimler Y, Cacho J, Czermak M, Dir. Délire des Négations Paris, Association freudienne internationale, coll. Le discours psychanalytique $1993 ; 191-219$.

[11] Baumont JP. Un trou noir. In: Baumstimler Y, Cacho J, Czermak M, Dir. Délire des Négations Paris, Association freudienne internationale, coll. Le discours psychanalytique 1993; 33-57.

[12] Cotard J. De l'origine psychomotrice du délire. Annales médicopsychologiques 1887: 351-7.

[13] Cacho J. Le délire de négations, Paris: Le discours psychanalytique - Éditions de l'Association Freudienne Internationale; 1993.

[14] Séglas J. Sémiologie et pathogénie des idées de négation, les altérations de la personnalité dans les délires mélancoliques. Annales médico-psychologiques 1889; 10: 5-26.

[15] Regis J. In: Cotard J, Camusset M, Seglas J, Dir. Le congrès de Blois 1892, Du délire des négations aux idées d'énormité. Paris, L'Harmattan1997; pp. 111-66.

[16] Cotard J. Du délire d'énormité, Annales médico-psychologiques. 1888: 465-9.

[17] Séglas J. Onzième leçon, Le délire dans la mélancolie. In: Leçons cliniques sur les maladies mentales et nerveuses, Salpêtrière 18871894. Paris: Asselin et Houzeau 1895; pp. 296-320.

[18] Seglas J. In: Cotard J, Camusset M, Seglas J, Dir. Le congrès de Blois 1892, Du délire des négations aux idées d'énormité. Paris, L'Harmattan1997; pp. 169-224.

[19] Resnick S. Syndrome de Cotard et dépersonnalisation. Information psychiatrique 1970; 46: 461-74.

[20] Lacan J. Le séminaire, livre II, Le Moi dans la théorie de Freud et dans la technique de la psychanalyse. Paris: Seuil 1978.

[21] Czermak M. La signification psychanalytique du syndrome de Cotard. In: Passions de l'objet, Paris, Joseph Clims 1986; pp. 20534.

[22] Baumstimler Y, Cacho J, Czermak M, dir. Délire des Négations, Actes du Colloque des 12 et 13 décembre. Paris: Association freudienne internationale, coll. Le discours psychanalytique; 1993.

[23] Freud S. Psycho-analytic notes on a auto-biographical account of a case of paranoïa (dementia paranoïdes). SE (1911c); 12: 3-80.

[24] Ferrey G. Le syndrome de Cotard et les négations fonctionnelles chez le sujet âgé. In: Baumstimler Y, Cacho J, Czermak M, Dir. Délire des Négations Paris, Association freudienne internationale, coll. Le discours psychanalytique 1993; 89-105.

[25] Descombey J-P. Introduction. In: Baumstimler Y, Cacho J, Czermak M, Dir. Délire des Négations Paris, Association freudienne internationale, coll. Le discours psychanalytique 1993; pp. 15-21.

[26] Czermak M. Patronymies, Considérations cliniques sur les psychoses. Paris: Masson; 1998.

[27] Lacan J. Le séminaire livre VII, L'éthique de la psychanalyse. Paris: Seuil; 1986

[28] Hulak F. Le syndrome de Cotard ou la clinique de l'entre deux morts. Information Psychiatrique 2003; 79(5): 415-21.

[29] Tevissen R. L'ombre douloureuse de la mélancolie, faute de vérité. In: Tevissen R, Ed. La douleur morale, Paris, Editions du temps. 1996; pp. 267-315. 